
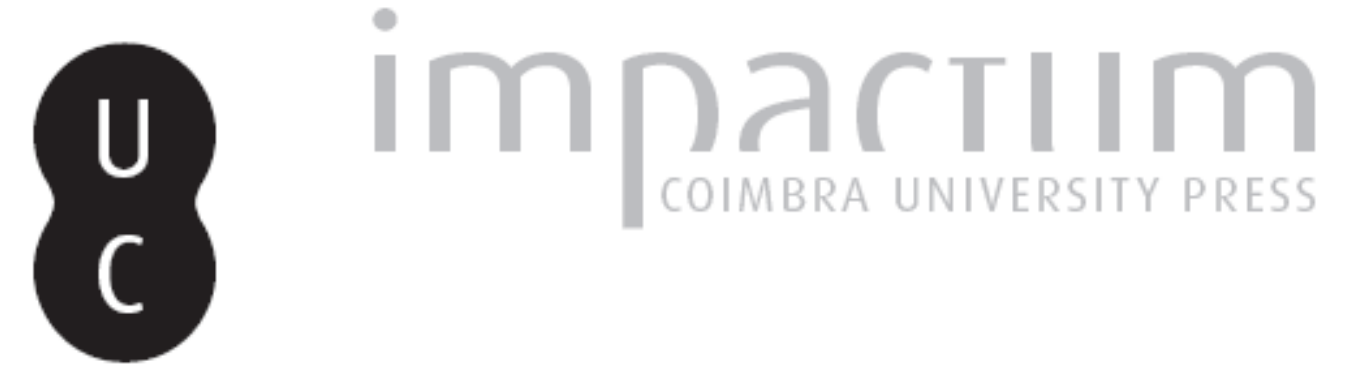

\title{
The form of soul in the Phaedo
}

\section{Autor(es): $\quad$ Prince, Brian D.}

Publicado por: Imprensa da Universidade de Coimbra

URL persistente: URI:http://hdl.handle.net/10316.2/42182

DOI: DOI:https://doi.org/10.14195/2183-4105_11_3

Accessed : $\quad$ 26-Apr-2023 10:19:18

A navegação consulta e descarregamento dos títulos inseridos nas Bibliotecas Digitais UC Digitalis, UC Pombalina e UC Impactum, pressupõem a aceitação plena e sem reservas dos Termos e Condições de Uso destas Bibliotecas Digitais, disponíveis em https://digitalis.uc.pt/pt-pt/termos.

Conforme exposto nos referidos Termos e Condições de Uso, o descarregamento de títulos de acesso restrito requer uma licença válida de autorização devendo o utilizador aceder ao(s) documento(s) a partir de um endereço de IP da instituição detentora da supramencionada licença.

Ao utilizador é apenas permitido o descarregamento para uso pessoal, pelo que o emprego do(s) título(s) descarregado(s) para outro fim, designadamente comercial, carece de autorização do respetivo autor ou editor da obra.

Na medida em que todas as obras da UC Digitalis se encontram protegidas pelo Código do Direito de Autor e Direitos Conexos e demais legislação aplicável, toda a cópia, parcial ou total, deste documento, nos casos em que é legalmente admitida, deverá conter ou fazer-se acompanhar por este aviso.

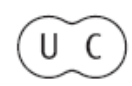




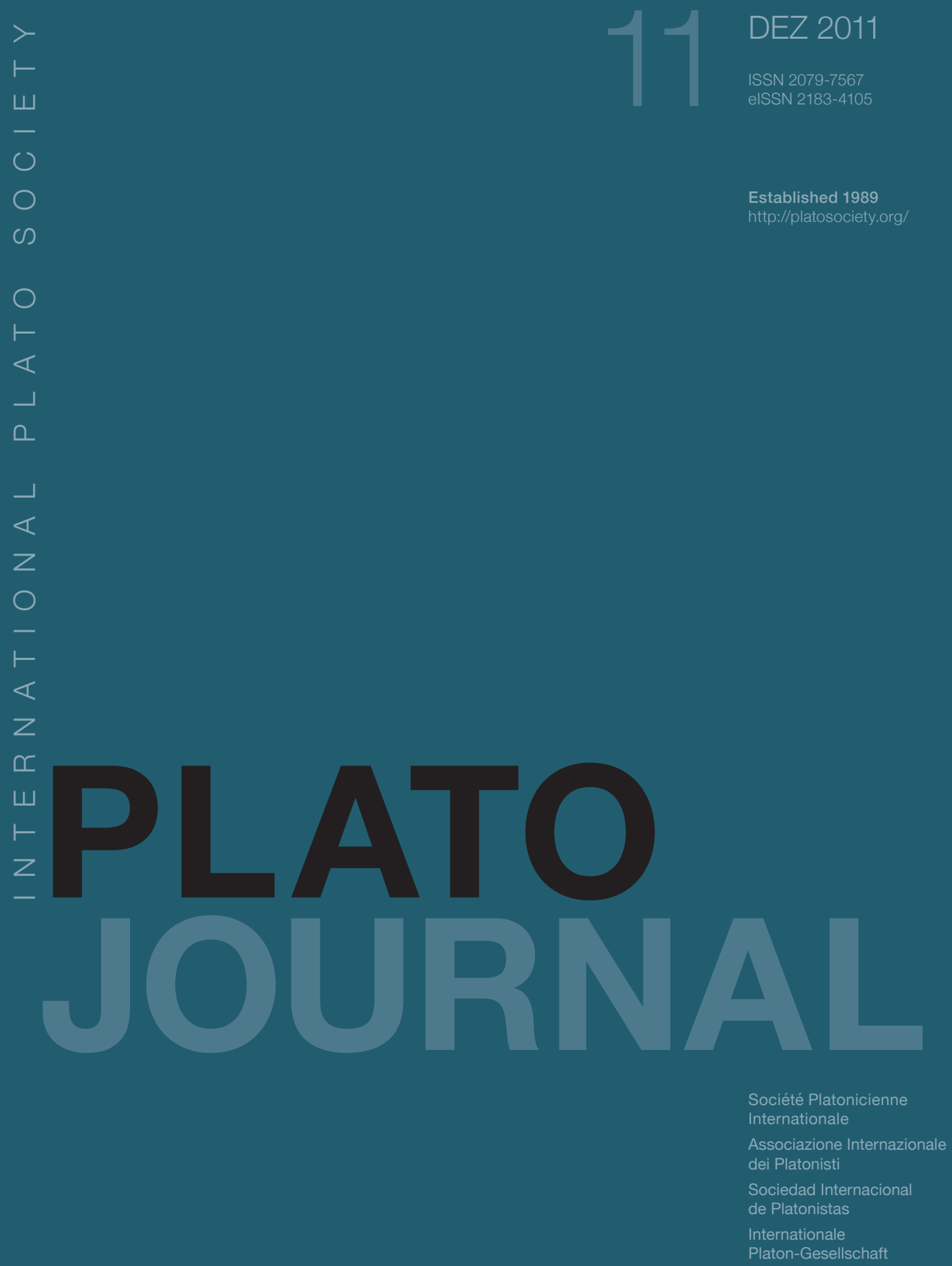




\title{
THE FORM OF SOUL IN THE PHAEDO
}

\author{
Brian D. PRINCE
}

The Phaedo's two most prominent philosophical topics are the theory of Forms and the immortality of souls. ${ }^{1}$ So the intersection of these should also be of central importance, and in particular, the question whether there is a Form of Soul in which individual souls participate. This question is salient for two reasons: first, souls receive specially focused attention in Plato's texts, and second, if the fact that a thing is a soul were not to be explained by participation in a Form, this would make souls highly unusual among the non-Form items in Plato's universe. ${ }^{2}$ That is, the Form of Soul occupies - or fails to occupy - a special slot in the metaphysics of the Phaedo: either it exists, and therefore souls have the same metaphysical explanation as visible items, or the Form of Soul does not exist, and therefore there is some quite different explanation of why something is a soul.

As I shall argue, there is a Form of Soul, and it plays a central role in the Phaedo's final argument for immortality. If this is correct, this Form will have other consequences for the relations between individual souls and Forms, and between individual souls and visible items. For example, if there is a Form of Soul, it seems clear that individual souls will follow the same pattern as visible items in their participation in eponymous Forms. The Form of Soul would raise other questions, including why it is never mentioned directly by Plato. I mention these further issues to show the importance of determining whether or not this Form is part of the theory in the Phaedo, but I will not investigate any of them here. My argument will be only that we should understand this Form as included in the theory of Forms in the Phaedo.

${ }^{1}$ I shall use the capitalized "Form" to refer to a transcendent Form, uncapitalized "form" for an immanent form. The uncapitalized word "soul" will refer to an individual soul. Translations are from Grube, revised by Cooper, except where noted. Italics in quotations from Plato are of course my own.

${ }^{2}$ I respond later to the objection that the Form theory in the Phaedo does not include Forms for substantives.

PLATO, The electronic Journal of the International Plato Society, n 11, 2011.

http://gramata.univ-paris1.fr/Plato/article101.html

(C) All rights of reproduction of any form reserved. 
On the other hand, if there is no Form of Soul, it is natural to ask how Plato explained what makes individual souls souls. The Phaedo shows a great deal of interest in how individual entities come to have their properties. And so far as the text shows, Plato understood being a certain kind of substance in the same way as he thought of how substances have their properties. ${ }^{3}$ So it would be hard to believe, perhaps even implausible, either that the question of the Form of Soul never occurred to Plato, or that, while the question did occur to him, he had no views on the subject. Plato's focus on Forms and souls in the Phaedo makes this question inescapable. But when we see how central it is to his interests, it also becomes clear how carefully he has steered around it. ${ }^{4}$ Nevertheless, if there is no Form of Soul, then souls are the only individuals for which Socrates offers no explanation of what makes them what they are in the Phaedo - surely a surprising fact about the most-discussed individuals in that text.

Let me enlarge slightly on the silence in the text: if there is a Form of Soul, why is Plato so cagey about mentioning it directly? We might try to explain Plato's silence by supposing that the Form of Soul would be or imply a definition, and Plato just did not know any definition of soul that he accepted when he wrote the Phaedo. But he speaks openly about Forms of Beauty and Goodness without endorsing any definition for them (e.g., Phaedo 100b6-7) - so this thought cannot explain his treatment of the Form of Soul. Second, while Plato nowhere explicitly affirms the Form of Soul, he also nowhere explicitly rejects it. He could easily have clarified his position on this question somewhere in his writings. These two points, then, only deepen the mystery.

This problem has been the object of only occasional comment, and even less sustained attention by scholars. A little more than a century ago, Archer-Hind and Burnet took opposite sides on this question in their respective commentaries on the Phaedo. First, Archer-Hind in 1894:

\footnotetext{
${ }^{3}$ See Hackforth's reluctant admission that this distinction will not absolve Plato of positing Forms for substances (1955, pp.144-145 and p.145 n.1).

${ }^{4}$ Dixsaut (1991, p.397), Loriaux (1975, p.132), and Guéroult (1926, p.488) have all noted that Plato's silence is too perfect to be accidental.
}

PLATO, The electronic Journal of the International Plato Society, n 11, 2011. http://gramata.univ-paris1.fr/Plato/article101.html (C) All rights of reproduction of any form reserved. 
It is true that an idea of soul is a metaphysical monstrosity; but we cannot escape it here... This is one of the errors which Plato rectifies in his later dialogues; for the present we must bear with it. ${ }^{5}$

In 1911 Burnet, apparently in reply:

There is not a word about the soul being itself a form or eidos, nor is such an assumption required. The soul may perfectly well be said to 'occupy' the body without being itself an idea. It is a simple military metaphor...and implies no metaphysical theory. ${ }^{6}$

Neither passage makes clear precisely what question is being addressed. The most reasonable inference, however, is that both authors are discussing whether a Form of Soul exists. The question whether individual souls are transcendent Forms should not arise, even if souls are in some ways very like those Forms. For each Form is unique (Republic 597b-d), while there are many souls. Second, if individual souls were Forms, they would be immortal by the most basic assumptions of the theory; it would be hard to make sense of the characters' extended attempt to determine whether souls are immortal, since no argument for this claim would be required.

Unfortunately, Archer-Hind provides only a hint of his reasoning that a Form of Soul is presupposed, and Burnet's answer does just as little to explain how the occupation of a body by a soul can dispense altogether with metaphysics. In short, neither position is obviously right.

Few authors since Archer-Hind and Burnet have continued this discussion. Part of the reason may be that the question has been put in an ambiguous way from the beginning. Burnet's phrase, "the soul being itself a form or eidos," can be read in three distinct ways: 1. "there is a Form of Soul"; 2. "individual souls are transcendent Forms"; and 3. "individual souls are immanent

\footnotetext{
${ }^{5}$ Archer-Hind (1894, p.116, commenting on 105d)

${ }^{6}$ Burnet (1911, p.123 ad 105d3, with Greek transliterated)
}

PLATO, The electronic Journal of the International Plato Society, n 11, 2011. http://gramata.univ-paris1.fr/Plato/article101.html (c) All rights of reproduction of any form reserved. 
forms." 7 When an author does mention the issue of souls and Forms, it is often difficult to decide which of these three theses is under discussion. A good example is Loriaux's comment, “...nous avons d'abord la conviction que, si le Phédon ne dit nulle part que l'âme est une Forme, c'est parce qu'il n'a jamais eu l'intention

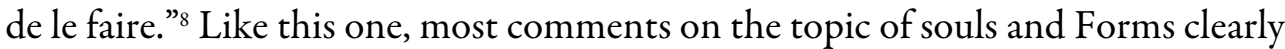
mean to reject one of the three theses, even if it is hard to decide which one. ${ }^{9} \mathrm{On}$ the other side of the question, I am aware of just two authors definitely endorsing the existence of the Form of Soul. ${ }^{10}$ Monique Dixsaut is the sole recent author of whom I am aware giving a direct argument which is clearly aimed against my thesis; I will respond to her view after expounding my own. ${ }^{11}$

I shall side with Archer-Hind in claiming that the Phaedo is best read as assuming a Form of Soul, which nevertheless goes unmentioned. While I would stop short of calling it a monstrosity, it is not hard to see the source of his worry. ${ }^{12}$ Forms are unchanging, but it is hard to reconcile something's being perfectly unchanging with the thought of it as alive or as a source or paradigm of life. Whether the charge of monstrosity sticks depends on how one understands the further details of the Form theory, and therefore lies beyond the scope of this paper. For example, a Form of Soul seems more monstrous if it is itself supposed to be alive; if it serves as a pattern of what it is to be alive, the charge of monstrosity is less convincing.

I shall argue for my conclusion in two ways. The first is contextual: throughout the Phaedo, Socrates characterizes his beliefs about Forms so as to suggest that there are very many of them, never suggesting any limit to this richness. If this were all we had to go on, we should conclude that there are many Forms, and that among them is a Form of Soul. Some have argued, however, that

7 This third reading is fueled by the possibility that the text introduces a class of "immanent forms" in addition to the transcendent ones, around $102 \mathrm{~b}$.

${ }^{8}$ Loriaux (1975, p.132)

${ }^{9}$ Examples include Dancy (2004, pp.312-313) and Gallop (1975, pp.213-214).

${ }^{10}$ These are Archer-Hind (1894) and Bestor (1988).

${ }^{11}$ At Dixsaut (1991, p.397 n.321).

${ }^{12}$ Archer-Hind seems to have been, at least to some extent, a Hegelian; a more satisfying explanation of his charge of "monstrosity" would probably include this fact as well.

PLATO, The electronic Journal of the International Plato Society, n 11, 2011. http://gramata.univ-paris1.fr/Plato/article101.html (c) All rights of reproduction of any form reserved. 
for various reasons we should instead think that Socrates intends to limit the number of Forms he posits; I address several of these claims in the course of making the case for a (much) wider set of Forms. In the second half of this paper, I analyze the final argument for the immortality of souls at Phaedo 95e-107a. There I give several reasons that the argument works better if a Form of Soul is understood as part of its machinery, reasons both internal to the passage's own logic and involving how the argument fits into the rest of the Phaedo.

\section{The Range of the Theory of Forms}

The first, and simplest, reason for acknowledging the Form of Soul is that Socrates several times characterizes Forms in ways that imply a very broad range of them. Taken in isolation from one another, each of these passages can be read as supporting either a narrower or a wider view of the range of Forms. But taken as a group, the passages support the wider reading. For the general and vague way in which Socrates puts his claims about Forms suggests that their range is indefinitely broad, that is, that there is no well-defined class to which he is trying to limit his ontological commitments. Since these statements are among the basic claims of the theory in the Phaedo, we should suppose that the theory includes a Form of Soul, unless there is specific evidence against that Form.

Now many writers on the Phaedo do accept that there are meant to be Forms for some quite broad class, such as all natural kinds or all predicates. But these comments are sometimes made hesitantly, and often do not point explicitly to the evidence in favor of this. ${ }^{13}$ As we shall see, the evidence is stronger than the hesitation would suggest: straightforward readings of several passages as well as logical considerations imply that there is a wide range of Forms, and this range would naturally include a Form of Soul. Given more explicit statements elsewhere (e.g. Rep. 596a), perhaps scholars have not thought it worth the trouble to adduce less definite passages in the Phaedo. But it is clear from the Phaedo alone that Socrates posits a wide range of Forms, most likely one for every general term or natural kind.

Forms are mentioned early in the Phaedo, when Socrates says,

${ }^{13}$ Without hesitation: Rickless (2007, pp.15-16, 29, 33), Finck (2007, p.7). More hesitantly: Bostock (1986), Fine (1993, p.358 n.3), Annas (1981), Hackforth (1955).

PLATO, The electronic Journal of the International Plato Society, n 11, 2011.

http://gramata.univ-paris1.fr/Plato/article101.html

(c) All rights of reproduction of any form reserved. 
I am speaking of all things such as Bigness, Health, Strength, and, in a word, the reality of all other things, that which each of them essentially is. (...kai tôn allôn heni logôi hapantôn tês ousias ho tugchanei hekaston on, $65 \mathrm{~d} 12-\mathrm{e} 1$ )

In this passage, the narrower reading claims that Socrates is only referring to Forms for things "such as (boion)" Bigness, Health, and Strength: that is, to some limited class of which these three are examples. The wider reading claims he is referring to Forms for "all things (hapantôn)," with the examples that follow intended to illustrate rather than limit the class of things that have Forms. The wider reading is supported by the second use of hapantôn, which suggests that there is a Form to explain everything (except the Forms themselves, of course): "in a word, the reality of all other things, that which each of them essentially is." This is a sweeping statement, not naturally read as referring to a limited class.

Later in the dialogue, Socrates explains his "safe" theory of generation and destruction:

...if there is anything beautiful besides the Beautiful itself, it is beautiful for no other reason than that it shares in that Beautiful, and I say that all things are this way. (kai panta dê houtôs legôn, 100c4-6) ${ }^{14}$

The word panta is ambiguous here: we must ask what class it is, all of whose members function just like beautiful things sharing in the Form of the Beautiful. Context provides the answer here: in this passage Socrates is beginning his answer to the general problem of generation and destruction that Cebes raised at $95 \mathrm{e} 10$. Socrates repeated his promise to solve this problem at $100 \mathrm{~b} 8$, so there is no doubt that he has this problem in mind just a few lines later as he gives the formula quoted above. Thus panta here must mean "all things [undergoing generation or destruction]." Now according to Socrates in the Phaedo, this class is made up of sensible things and souls. Sensibles are the primary examples of things that are generated and destroyed in this dialogue. Socrates argues, of course, that souls themselves are neither generated nor destroyed, but they nevertheless participate

${ }^{14}$ Author's translation, following a suggestion by Harvey Yunis.

PLATO, The electronic Journal of the International Plato Society, n 11, 2011.

http://gramata.univ-paris1.fr/Plato/article101.html

(C) All rights of reproduction of any form reserved. 
in generation and destruction by acquiring and losing properties. For example, they become more or less virtuous, knowledgeable, or attached to the body (e.g. 64d-e, 65b). To account for all the properties gained and lost by the class of sensible things, there must be a very broad range of Forms. So this statement too implies a wide range of Forms, which is most naturally taken as including a Form of Soul.

Other texts also imply a wide range of Forms. In the course of the Argument from Recollection (72e-77a), Socrates says of the Forms, "we refer all the things we perceive to that reality..." (...kai epi tautên ta ek tôn aisthêseôn panta anapheromen..., 76d9-e1). Here the set of all visible things is contrasted with the set of Forms, and Socrates claims that there is a member of the second group corresponding to each member of the first, implying that there is a Form corresponding to every perceptible thing and property. Souls, of course, are not perceptible; but if there are Forms for every perceptible thing, and no denial of a Form of Soul, it is hard to see why we should think the theory excludes a Form of Soul.

If we now return to the formula of $65 \mathrm{~d}-\mathrm{e}$ above - "the reality (ousia) of all other things, that which each of them essentially is (on)" - we find another reason for admitting the Form of Soul. This formula describes Forms as either the "essences" or the "realities" of all non-Form items (and possibly as both). If Forms are essences, then since participation in Forms explains the possession of properties in the Phaedo, Forms are responsible for the essences of non-Form items. ${ }^{15}$ To deny that there is a Form of Soul, then, is to deny that there is any essence of souls, anything that is what it is to be a soul. For this passage implies that having a Form is a necessary condition for a thing's having an essence. ${ }^{16}$ It would follow that the final argument for the soul's immortality is doomed from the start, since its key move is the claim that individual souls are essentially related to the Form of Life. Something that lacks an essence cannot be essentially related to anything. Socrates' claim that souls are essentially alive would accomplish nothing, since they could lose this property at any time.

\footnotetext{
${ }^{15}$ I assume that this statement can be suitably modified for any plausible answer to the question of what precisely the Forms are.

${ }^{16}$ On this point see also Griswold (1986, p.89).
}

PLATO, The electronic Journal of the International Plato Society, n 11, 2011.

http://gramata.univ-paris1.fr/Plato/article101.html

(c) All rights of reproduction of any form reserved. 
If Forms are the "reality" of non-Form items, then if there is no Form of Soul, there is no reality of souls. This would make individual souls less than real. This view does not sit well with Socrates' explicit claims about individual souls, for example that it is possible to "escape from the body and observe things in themselves with the soul by itself" (66e), or that individual souls are immortal. Without a Form of Soul, Socrates needs to explain how he can hold all these views consistently, whereas with a Form of Soul, these problems (at least) do not arise. His failure to address these problems, then, suggests once more that the Form of Soul is among his assumptions.

The same point emerges from Phaedo 80a10-b5, where souls are classified as invisible. Among the properties of invisible things is being intelligible (noêtôi, 80b1). Plato's explanation (in the same passage) of why some things are intelligible is the same as his explanation of having an essence: both depend on the Form of the thing or property in question (Phaedo 79a-d). To claim that individual souls are intelligible but lack a Form would be inconsistent with Socrates' analysis in this passage.

Given Socrates' general and sweeping statements about Forms, the Form of Soul is at least likely to be one of the Forms. In addition, simple arguments about essence, reality and intelligibility have just shown that this Form is required: to deny it, one would need to suppose that Socrates has in mind a significant chunk of metaphysics that he keeps entirely hidden from his friends. We have no justification for this assumption. The inference consistent with the text is that there is a Form of Soul, along with a vast range of other Forms.

We can now turn to some passages and arguments that have been taken to count against my claims. These are not arguments against the Form of Soul specifically, but attempts to limit the range of Forms in ways that would also rule out the Form of Soul. Some writers accept that there are Forms posited in the Phaedo for every general term, or for every natural kind, while a number expressly deny this. ${ }^{17}$ Among the proposals for a limited range of Forms, some have

${ }^{17}$ Those accepting a rich domain of Forms include Rickless (2007, pp.15-16, 29, 33) and Finck (2007, p.7). Those denying a rich domain of Forms include Crivelli (2008, pp.218-220), Moravcsik (2000, p.56), Fine (1987, p.376 n.42), Bostock (1986, p.176, although not definitely), Annas (1981, p.221) and Hackforth (1955, p.142). See also below. Most writers cited here are discussing a broader set of dialogues than just the Phaedo.

PLATO, The electronic Journal of the International Plato Society, n 11, 2011.

http://gramata.univ-paris1.fr/Plato/article101.html

(c) All rights of reproduction of any form reserved. 
observed that most of the unambiguous examples of Forms in both the Phaedo and Republic have opposites, and so have claimed that the theory only posits Forms for opposite qualities. ${ }^{18}$ But both dialogues also contain examples of Forms that have no opposite, so this line cannot hold. ${ }^{19}$

A second way of arguing for a limited range of Forms is based on this passage: ${ }^{20}$

What of the many beautiful particulars, be they men, horses, clothes, or other such things, or the many equal particulars, and all those which bear the same name as those others? Do they remain the same or, in total contrast to those other realities, one might say, never in any way remain the same as themselves or in relation to each other? - The latter is the case; they are never in the same state. (78d10-e6)

One might read this passage as circumstantial evidence that the range of Forms is limited. For Socrates seems to come close here to speaking of Forms for substantives in the cases of men, horses, and clothing. But careful reading shows - correctly - that he is not referring to those Forms after all. Instead, he is only mentioning those particulars insofar as they are beautiful or equal, and thus his reference is only (directly) to the Forms of Beauty and Equality. So this might be taken as a passage in which Plato has gone out of his way to avoid mentioning a rich domain of Forms, from which it seems a reasonable inference that he only wishes to posit a limited number of Forms.

But this argument is weaker than it first appears. If we reflect on Cebes' answer, it is clear that he is thinking of visible entities as a single class. He does not do any reasoning about beautiful or equal things to arrive at his answer; instead, he reasons that all visible things change constantly, and it follows

${ }^{18}$ These include Bostock (1986, p.176, recognizing the argument without endorsing it), Dorter (1982, p.125), Annas (1981, p.223) and White (1978, p.149, without endorsing).

${ }^{19}$ Fire and Snow in the Phaedo, Bed and Table in the Republic (Harte 2008, p.199). I argue below that Fire and Snow are Forms in the Phaedo.

${ }^{20}$ This argument has not been proposed in the literature, so far as I am aware. But it is worth adding to the list of arguments contra a wide range of Forms, as should be clear from its explication.

PLATO, The electronic Journal of the International Plato Society, n 11, 2011.

http://gramata.univ-paris1.fr/Plato/article101.html

(c) All rights of reproduction of any form reserved. 
immediately that this is true of beautiful and equal visible things. So the import of the question is to contrast the visible and invisible realms (just as it also was at $76 \mathrm{~d} 9$, considered above). Given this purpose, it is far from certain that no Forms for substances (such as men, horses, etc.) are implicated, in spite of their not being mentioned directly. Instead, Cebes seems to assume that Forms are involved in the explanation of any property of any visible entity. The passage does not, then, provide evidence against the possibility of Forms for every property and substance.

A third strategy is based on the final argument for immortality, where Socrates sums up his "safe" answer by telling Cebes:

...you would loudly exclaim that you do not know how else each thing can come to be (bekaston gignomenon) except by sharing in the particular reality in which it shares...(101c2-4)

The phrase hekaston gignomenon implies that this claim covers all cases of becoming. Again, this passage occurs after Socrates has promised to respond to the general problem of becoming and perishing raised by Cebes at 95e10, and has re-affirmed his promise at $100 \mathrm{~b} 8$. So for every case of becoming there is some Form in which the thing comes to share. Prima facie, this passage posits a Form for everything that comes to be, both properties and the substances in which they inhere.

Now some scholars, attempting to absolve Plato from a rich domain of Forms, have distinguished two senses of "becoming": it may refer to a thing's coming to have a property, or to the generation and perishing of a substance. ${ }^{21}$ The thought is that Socrates only means to discuss the former type of generation in this passage, and is not discussing the generation or destruction of substances. On this reading, "each thing" would imply Forms only for the properties that things can come to have: tallness, oddness, heat, cold, etc. Since souls are substances, and this passage is not about substances, this line of thinking goes, this passage cannot imply that there is a Form of Soul.

${ }^{21}$ Loriaux (1975, p.98)

PLATO, The electronic Journal of the International Plato Society, n 11, 2011.

http://gramata.univ-paris1.fr/Plato/article101.html

(c) All rights of reproduction of any form reserved. 
But in the first place, it is not certain that Plato recognizes this distinction.22 However, grant for the sake of argument that he did. Socrates' examples in the Phaedo are mostly, if not all, about coming to have a property. This makes it easier to think that no Forms for substances are implicated in the Phaedo. However, Socrates has introduced the Forms to explain how he has investigated "the cause of generation and destruction" (peri geneseôs kai phthoras tên aitian, 95e10). He then describes his youthful interest in knowing "the causes of everything, why it comes to be, why it perishes, and why it exists" (eidenai tas aitias hekastou, dia ti gignetai hekaston kai dia ti apollutai kai dia ti esti; 96a8-9). Since the point of the discussion is to determine whether souls can be destroyed, it is a strain to suppose that this sentence excludes substances - and therefore souls - from the reference of "everything."

Aristotle also read this passage without the alleged distinction. As Hackforth reluctantly acknowledges, Aristotle's discussion of the theory of Forms at $G C 335 \mathrm{~b} 7 \mathrm{ff}$., which he attributes to "Socrates in the Phaedo," shows that Aristotle took the theory to be about the generation and destruction of substances as well as properties. According to Aristotle, the coming-to-be of both properties and substances is explained by sharing in a Form, while destruction is explained by losing the Form. Hackforth is forced to this conclusion by the fact that, while gignetai can have the sense of gignetai ti, coming to be something, i.e. acquiring a property, phtheiresthai (the word used by Aristotle) cannot mean "to lose a property," but only "to perish," as in the destruction of a substance. ${ }^{23} \mathrm{On}$ the theory in the Phaedo, then, everything that comes to be - both substances and properties - does so by sharing in a Form.

A more recent position that would block my thesis has been proposed by Paolo Crivelli, arguing that Phaedo 102b1-3 does not imply a wide range of Forms. ${ }^{24}$ Two translations of the key phrase will show where the issue lies. Phaedo says,

\footnotetext{
${ }^{22}$ A special effort would be required to mark it in ancient Greek, and Plato never makes such an effort.

${ }^{23}$ Hackforth (1955, pp.144-145 n.1)

${ }^{24}$ Crivelli (2008, pp.218-219)
}

PLATO, The electronic Journal of the International Plato Society, n 11, 2011.

http://gramata.univ-paris1.fr/Plato/article101.html

(c) All rights of reproduction of any form reserved. 
It was agreed that each of the Forms existed, and that other things acquired their name by having a share (metalambanonta) in them...(Grube/Cooper)

It was agreed that each of the Forms exists and the other things that partake (metalambanonta) of these derive their names from these themselves. (Crivelli)

The difference arises from the reading of the participle metalambanonta, "having a share in." Grube takes the participle instrumentally, while Crivelli understands it as representing a relative clause limiting the class of things doing the partaking. Both readings are grammatically possible. ${ }^{25}$ Crivelli's version does not imply a wide range of Forms, since Socrates is saying that only things that partake of Forms get their names from those Forms. Grube's version, on the other hand, implies a wide range of Forms, since it says that everything (except the Forms themselves) gets its names from the Forms it partakes of. But context gives us a clear reason for preferring Grube's understanding. For the remainder of the paragraph shows that the characters think they have just established a principle on which, whenever any particular receives a name, this must be because it participates in the Form of the same name. Socrates continues:

If you say these things are so, when you then say that Simmias is taller than Socrates but shorter than Phaedo, do you not mean that there is in Simmias both tallness and shortness? - I do. (102b3-6)

Socrates' inference here is only valid on Grube's causal translation. On Crivelli's understanding, Socrates ought to show first that the Forms of Tallness and Shortness exist, participation in which explains the names "tall" and "short." But none of the characters thinks this step is necessary, and the best explanation of this is that they take the previous agreement (102b1-2) to have taken care of this. Being called by a name implies without further argument that one participates in the Form of that name. Contrary to Crivelli's conclusion, this inference rule implies a Form at least for every (basic) predicative expression.

Given the persistence of these claims through the dialogue, it would be surprising if some significant entity with a name failed to have a corresponding

${ }^{25}$ The difference in tense ("existed" versus "exists") is not relevant here.

PLATO, The electronic Journal of the International Plato Society, n 11, 2011.

http://gramata.univ-paris1.fr/Plato/article101.html

(c) All rights of reproduction of any form reserved. 
Form. Souls are, for Plato, one of the most significant entities, so we should suppose that the theory includes a Form of Soul.

The fifth and final argument I shall consider against a rich domain of Forms is also the best-known and most influential. ${ }^{26}$ Alexander Nehamas has argued that the theory in the Phaedo is restricted to a special class of adjectives, those that are "incomplete." ${ }^{27}$ By "incomplete" he means adjectives that are "either attributive or relational." Attributive adjectives are those that make implicit reference to what is normal for some group. A baby elephant, for example, is small for an elephant, but large compared with many other groups. Relational adjectives are those that require that we fill in more than one place to get a complete expression. "Fred is larger" is incomplete, since we must specify who or what Fred is larger than before we have a complete assertion. Nehamas claims that the arguments employed in the Phaedo support no Forms but those for incomplete adjectives.

Nehamas' argument begins by noting that the Argument from Recollection (72e-77a) claims that some properties go with their opposites whenever we observe them. Two sticks or stones that seem equal, for example, never seem perfectly equal; in some way they always also appear unequal. "Beautiful" and "good" are similar: things that instantiate these properties in some sense also instantiate their opposites. Since each of these properties seems to be instantiated along with its opposite in all observable cases, Socrates concludes that nothing justifies our ascribing one of these adjectives to an object rather than its opposite. Helen is beautiful compared with other women, but ugly compared with a goddess. It cannot then be true simpliciter that Helen is beautiful, since the opposite assertion has just as much warrant. Nehamas argues that the theory of Forms in the Phaedo is created expressly to solve this problem. Since the problem

${ }^{26}$ Nehamas gives the most developed form of the argument $(1973,1975)$. The influence of his formulation is seen in Griswold (1981, pp.138-139) and White (1979, pp.31-32), who both accept it without criticism. Most tellingly, in his Hackett student edition Plato: Five Dialogues, Cooper lists Nehamas' earlier article as one of just eight bibliographic entries for the Phaedo (Cooper 2002). The following writers also mention, but do not all endorse, Nehamas' argument: Harte (2008, p.203 n.32), Finck (2007, p.28 n.57), Devereux (2003, p.97), Levin (2001, p.96 n.43) and Gill and McCabe (1996, p.23 n.30).

${ }^{27}$ Nehamas (1973, p.470) and Nehamas (1975, pp.108-109).

PLATO, The electronic Journal of the International Plato Society, n 11, 2011.

http://gramata.univ-paris1.fr/Plato/article101.html

(c) All rights of reproduction of any form reserved. 
only arises for incomplete terms, he thinks, there is no evidence that the theory was ever intended to handle a wider class.

Further, Nehamas thinks there is a logical reason that the argument cannot be extended to other terms, and in particular to terms for substances. Since the argument depends on the fact that certain adjectives are always instantiated with their opposites, there must be something stable for them to be instantiated in. For example, if the theory applied to Helen's status as a person just as it does to her beauty, she would no more be a person than not a person. In this case, there could not be any compresence of opposites for her beauty, size, or other incomplete properties, and we know that Plato is committed to the compresence of opposite for them. "Accordingly," Nehamas writes, "when Socrates generalizes to 'the beautiful, the good, and all such being' at $74 \mathrm{~d} 8-9$...we have no license to infer that any Forms have been generated other than those corresponding to those properties which are instantiated along with their opposites." 28

To begin, this account is factually mistaken: some Forms mentioned in the Phaedo are not incomplete. The Forms of Oddness (103e2-104b4) and Life (105d5-6) each refute Nehamas' claim: no one denies that the text mentions them, and neither is incomplete. ${ }^{29}$ Three needs no comparison with anything else to establish its oddness, nor is there any relatum needing to be filled in to complete the thought that three is odd. Finally, and as a consequence of failing the two tests just mentioned, there is no sense in which three is both odd and not odd. Again, the Form of Life is of paramount importance in the dialogue, and if Life were an incomplete property, things that partake of it would suffer from compresence of opposites. It would follow that no soul could be more alive than dead, and this would make nonsense of Socrates' efforts to show that souls are immortal. ${ }^{30}$

Suppose a scientist offers evidence that polio is caused by a certain kind of germ. Nehamas' position is analogous to thinking that this scientist must

\footnotetext{
${ }^{28}$ Nehamas (1973, p.469)

${ }^{29}$ Also noted by Malcolm (1991, p.79) and Patterson (1985, pp.99-100).

${ }^{30}$ See the moves Socrates makes at $104 \mathrm{~b}-105 \mathrm{e}$ : it is crucial to his argument that souls do not admit both life and death simultaneously.
}

PLATO, The electronic Journal of the International Plato Society, n 11, 2011. http://gramata.univ-paris1.fr/Plato/article101.html (c) All rights of reproduction of any form reserved. 
subscribe to a theory on which the only germs that exist cause polio; that is, that she could not also believe in other sorts of germs. The fallacy lies in taking one of Plato's arguments for Forms, the Argument from Recollection, as co-extensive with the theory it is used to support. But there is no reason that the theory cannot cover more territory than whatever range the Argument from Recollection may support, just as the germ theory posits more kinds of germs than the evidence for polio germs can support. So when Nehamas writes, "[Plato] gives no argument which commits him to [the] existence [of the Form of Bed], and he does give arguments [sc. from the compresence of opposites] which preclude it," he reaches too far. ${ }^{31}$ So even if we grant for the moment that no argument in the Phaedo commits Plato to Forms of substantives, it is nevertheless not the case that any argument precludes them. ${ }^{32}$ It is true that the Phaedo fails to give adequate arguments for the existence of such a wide range of Forms, but this is no reason for ignoring the signs that this is the theory Socrates has in mind and intends to discuss.

\section{The final argument for immortality in the Phaedo}

The logic of the final argument for the immortality of souls (100b-107a) provides a different kind of evidence for the Form of Soul. The difficulties of this argument are myriad, but most of these make no difference in deciding whether the argument presupposes a Form of Soul.

The core issue comes to this: for the Form of Soul not to be involved in the argument, two claims must be true.

1. Each occurrence of the word psuche in the text must refer to an individual soul rather than a Form.

2. Even if this Form is never mentioned by the text, the logic of the argument must work without appealing to a Form of Soul.

The first claim can be sustained, but the second leads to implausible readings.

Socrates' decision to begin the argument by introducing the theory of Forms (100b-102a) implies that Forms are somehow essential to his proof. The proof s

\footnotetext{
${ }^{31}$ Nehamas (1973, p.463).

${ }^{32}$ The same point is made by Fine (1993, p.326 n.61, 358 n.3).
}

PLATO, The electronic Journal of the International Plato Society, n 11, 2011. http://gramata.univ-paris1.fr/Plato/article101.html (C) All rights of reproduction of any form reserved. 
conclusion is marked by Socrates' saying, “Therefore soul (psuche)...is most certainly deathless and indestructible and our souls (hai psuchai) will really dwell in the underworld" (107a). Here the word for soul occurs the first time without an article, so context provides the only way to decide whether this refers to a transcendent Form of Soul or individual souls. But both the plural form that follows in the same sentence and the context suggest that both references are to individual souls. First, it is a basic claim of the theory of Forms that no Form ever changes or is destroyed, so a proof that the Form of Soul is "deathless and indestructible" would be redundant. Second, the challenge that prompted Socrates to take up this argument was about individual human souls that enter and leave human bodies. It would be a gross non sequitur if Socrates were to respond by proving the immortality and indestructibility of something else. So the argument begins with the Forms and ends with individual souls. Individual souls must therefore be related to Forms in some way that can generate an argument for the immortality of souls.

Socrates' first substantive claim in the proof is what he calls a "safe" answer to any question about why some individual has some property (asphales, $100 \mathrm{~d} 8$, e1): "...if there is anything beautiful besides the Beautiful itself, it is beautiful for no other reason than that it shares in that Beautiful." He also calls this answer "simple" (haplôs, 100d3-4). Part of the safety of this answer is that it can be mindlessly applied to anything except the Forms themselves; in the same passage, Socrates also calls it "naïve" and "perhaps foolish" to emphasize its ease of use. Only on the assumption that the domain of Forms is extremely rich will he be able to use the "safe" answers without fear of contradiction. This claim, like those reviewed earlier, suggests few if any limits on the range of Forms.

Our next step is to touch on one of the central interpretive issues for this passage, the question whether the text mentions immanent forms. Having referred to transcendent Forms several times earlier in the dialogue, Socrates now begins speaking about the "tallness in Simmias" and the "shortness in Simmias." Opinion is divided over whether these phrases can be explained by transcendent Forms and individuals alone, or whether we should also posit a separate class of "immanent forms." An immanent form is something like an instance of a transcendent Form that happens to be located "in" a sensible particular. Fortunately we do not need to decide this issue here.

PLATO, The electronic Journal of the International Plato Society, n 11, 2011.

http://gramata.univ-paris1.fr/Plato/article101.html

(C) All rights of reproduction of any form reserved. 
Some writers think the word psuche in the final argument refers to the immanent form of soul. ${ }^{33}$ Suppose this is true even once: if so, it follows immediately that there is also a transcendent Form of Soul. For the Phaedo's only account of immanent forms makes them parasitic on transcendent versions of themselves: immanent forms, again, are instances of transcendent Forms. But there can be no instances of non-existent transcendent Forms. Any reading that tries to deny that there is a Form of Soul, then, will have to insist that every occurrence of psuche refers to an individual soul. These are the readings I will be discussing from here on, since all others will admit the Form of Soul. The question we must ask of these remaining readings is whether, in addition to taking each instance of psuche to refer to an individual, they can also explain how the final argument works without using the Form of Soul.

Socrates next introduces a series of examples culminating in the claim that souls are "Form-bringers": that is, whenever an individual soul occupies a body, it brings along with it the Form of Life. Socrates describes "Form-bringers" as:

...[the] kind of things [that] while not being opposites to something, yet do not admit the opposite, as, for example, the triad, though it is not the opposite of the Even, yet does not admit it because it always brings along the opposite of the Even...(104e8-105a5)

Socrates' definition of Form-bringers includes two claims: 1. The thing occupied by the Form-bringer cannot admit the opposite of the Form brought along, and 2. The Form-bringer itself excludes the opposite of the one it brings along. I will refer to this second claim as the Form-bringer Exclusion Principle, or FEP. ${ }^{34}$ The FEP is crucial to proving the soul immortal: on the assumption that souls bring life to certain bodies, plus the observation that those bodies are alive, the FEP allows Socrates to conclude that the souls occupying them are themselves alive.

${ }^{33}$ Silverman (2002, p.63), Keyt (1963, p.169) and Hackforth (1955, pp.161-162).

${ }^{34}$ Form-bringers are defined twice, at $104 \mathrm{~d} 1-3$ and $105 \mathrm{a} 2-5$. Both definitions allow more than one grammatical understanding, so that they can be taken as saying that the Form-bringers are either the things that do the occupying, or the things that are occupied. Gallop (1975, p.202 ff.) gives the most detailed account of both possibilities. Although the difference makes no difference for my argument, for simplicity I shall follow the first understanding of the definitions, assuming that Form-bringers occupy other items.

PLATO, The electronic Journal of the International Plato Society, n 11, 2011. http://gramata.univ-paris1.fr/Plato/article101.html (c) All rights of reproduction of any form reserved. 
So the idea of a Form-bringer involves four roles: 1. the Form-bringer, 2. the thing it occupies, 3. the opposite Form that is brought along, and 4. the opposite that is excluded. Between 103d and 105b, Socrates gives several examples of this pattern, of which the most important are fire, snow and three. Our next task is to clarify which items are filling which roles as he moves through these examples. This will show which options are open for understanding the case of souls, with which this series ends.

"So the hot is something other than fire, and the cold is something other than snow? ...You think, I believe, that being snow it will not admit the hot..." $(103 \mathrm{~d} 2-6)$. We need to decide which roles are being played by "fire" and "the hot." First, fire and snow here must be sensible, physical things - presumably this is why Cebes is able to say without reflection what snow does in the presence of the hot. The point would require more explanation or consideration had Cebes understood that the Forms (or forms) of Fire and Snow were meant. "The hot" and "the cold" are clearly the opposites brought along by the Form-bringers in one case, and excluded in the mirror case: fire bringing along "the hot," while excluding "the cold," and snow bringing along "the cold" while excluding "the hot." The question, then, is whether the physical fire and snow are playing the role of Form-bringers (role 1) or the role of things occupied (role 2). We can make progress on this question by establishing which Form(s) the Form-bringer compels the thing occupied to have, when the first definition of Form-bringers specifies that they "compel whatever they occupy...to contain their own Form..." $(104 \mathrm{~d} 1-3)$.

It is clear enough that one of a pair of opposites is being brought along, and the other member of the pair excluded. But in addition to this, the Formbringer is said to "mê monon anagkazetai tên hautou idean auto ischein..." (104d2). What is the identity of tên hautou idean, "its own Form"? There are three answers worth considering: 1. the Form of the Form-bringer (e.g., the Form of Fire brings the Form of Fire to whatever it occupies); 2. the Form of the opposite brought along (e.g., the Form of Fire brings the Form Hot to whatever it occupies); 3. some other Form already belonging to the thing occupied, not identical with either (1) or (2) (e.g., the Form of Fire brings the Form of Stick to a stick it occupies).

PLATO, The electronic Journal of the International Plato Society, n 11, 2011.

http://gramata.univ-paris1.fr/Plato/article101.html

(C) All rights of reproduction of any form reserved. 
I favor the first reading, as each of the other two produce logical difficulties. On the second reading, the Hot might count as fire's "own" Form, on the ground that fire brings the Hot with it. But Socrates contrasts "its own Form" with the Form of "some opposite" within the same sentence. So "its own Form" does not seem to refer to either of the opposites involved in the idea of Formbringers. The third reading is ruled out by the grammar of the sentence: the phrase tên hautou idean is the direct object of the verb anagkazetai. For example, physical snow in the role of Form-bringer might be thought to "occupy" a human being, thus "compelling" the human to participate in the Form of Human as "its [the human's] own Form." While it is reasonable to describe the Form Human as a physical human being's "own" Form, it is counterintuitive to suggest that a Form-bringer such as snow has anything to do with the fact that humans participate in the Form Human. Nor does anything in the text support this suggestion. "Its own Form" must also refer to some Form that the Form-bringer compels the thing occupied to have, a Form which it would not otherwise have. I therefore think the Form-bringer compels whatever it occupies to have not only the Form-bringer's own Form, but also the Form of some opposite. So if fire is a Form-bringer, it compels whatever it occupies to have the Form Fire within it, as well as the Form Hot.

Now having a Form within oneself is equivalent to being called by its name, so that if fire or snow were to occupy something, compelling it to contain the Forms of Fire or Snow, it would follow that the thing occupied would itself become another instance of fire or snow.But in the case of snow there is nothing that satisfies this description, that is, there is nothing that sensible snow "occupies," thereby making the thing occupied into more snow. ${ }^{35}$ The sensible fire and snow that Socrates mentions $(103 \mathrm{~d} 2-6)$ must, therefore, be things occupied (role 2). What, then, are the Form-bringers (role 1)? The only candidates are the Forms of Fire and Snow: by the principle enunciated in the text they do compel whatever they occupy to contain their own forms, that is, to become sensible instances of fire and snow. And this, after all, is just the "safe answer" that Socrates has been advocating.

${ }^{35}$ The case of fire is less certain, since it is plausible to think that if a physical fire occupies a combustible thing, it will indeed cause that thing to itself become an instance of fire, that is, to catch on fire. But the relation Socrates has in mind here must work for both fire and snow. Since this reading clearly fails in the case of snow, it cannot be correct for fire either.

PLATO, The electronic Journal of the International Plato Society, n 11, 2011.

http://gramata.univ-paris1.fr/Plato/article101.html

(c) All rights of reproduction of any form reserved. 
The text thus implies that the Form of Snow (role 1) occupies a lump of sensible snow (role 2), making it into an instance of snow, and at the same time bringing along the Form of Cold (role 3). ${ }^{36}$ Parallel reasoning, of course, shows that a Form of Fire is also assumed in this passage. (The Forms of Fire and Snow are therefore precedents for what I shall claim about the Form of Soul: each is required by what Socrates says, but neither is explicitly mentioned by the text. ${ }^{37}$ ) Finally, Socrates brings back the safe explanation explicitly when he says, "what the Form of Three occupies must be not only three but also odd" (104d5-7). This case shows that the Form of Three is the Form-bringer, and confirms again that Forms of Fire and Snow are implied in the previous example.

For clarity, here is the parallelism I detect across the cases of fire, snow, and three in detail. There are four roles to be filled in each case: 1. the Formbringer; 2. the thing occupied; 3. the opposite brought along; 4. the opposite excluded. The Form-bringers are the Forms of Fire, Snow, and Three; the things occupied are (physical instances of) fire and snow, and a group of three things (this last identification is vexed by the question of how Plato thought of numbers); the opposites brought along are the Hot (brought by Fire), the Cold (brought by Snow), and the Odd; the opposites excluded are the Cold (excluded by Fire), the Hot (excluded by Snow), and the Even. As noted above, Formbringers need not always be transcendent Forms; here we can add that the things occupied need not always be physical things. ${ }^{38}$

${ }^{36}$ Bestor (1988, p.41) takes the same view (Bestor's view of the final argument has broad similarities to mine). Note that while I am arguing that the Form-bringers must be transcendent Forms in this case, not all Form-bringers are Forms. In particular, the souls that are Form-bringers at the end of the argument must be individuals.

37 There is an additional reason to adopt the reading I am advocating. Suppose one prefers the reading I have just rejected, on which, when Socrates observes that "being snow it will not admit the hot," "snow" refers not to the thing occupied (role 2), but to a Form-bringer (role 1). (As before, I assume that physical snow is the kind under discussion.) This would then be an early statement of the FEP. The difficulty with this reading is that this putative early statement of the FEP occurs at 103d5-6 for snow, and 103d10-11 for fire. Form-bringers are first defined one page later (104d1-3), but the first definition fails to include the FEP; only the second definition (105a2-5) expresses the FEP. So this reading would need to explain why Socrates begins by giving an example of the FEP, but then fails to include the FEP in his first definition, only getting the definition right a page and a half later.

${ }^{38}$ At this point, readers might wonder if I am committing myself to a version of the Formtheory that has other problems that could undermine my thesis. For example, an anonymous

PLATO, The electronic Journal of the International Plato Society, n 11, 2011.

http://gramata.univ-paris1.fr/Plato/article101.html

(c) All rights of reproduction of any form reserved. 
As Socrates arrives at the case of the soul, then, both of his extended examples have presupposed the "safe" explanation as part of the more "sophisticated" explanation he is now adding to it. In each case, the Form-bringer compels the thing occupied to have the Form-bringer's own Form (which in these examples is just the Form-bringer itself), and this constitutes the "safe" answer. The Form-bringers also compel the things occupied to accept one of a pair of opposites, and these are what Socrates calls the "sophisticated" answers.

After explaining these cases and defining the Form-bringers for the second time, Socrates inserts two briefer examples - fire (again) and sickness - before turning to the soul:

Tell me again from the beginning...and do not answer in the words of the question, but do as I do. I say that beyond that safe answer, which I spoke of first, I see another safe answer. If you should ask me what, coming into a body, makes it hot, my reply would not be that safe and ignorant one, that it is heat, but our present argument provides a more sophisticated answer, namely, fire, and if you ask me what, on coming into a body, makes it sick, I will not say sickness but fever. Nor, if asked the presence of what in a number makes it odd, I will not say oddness but oneness, and so with other things. See if you now sufficiently understand what I want. - Quite sufficiently. $(105 \mathrm{~b} 5-\mathrm{c} 7)$

reader has suggested that if Form-bringers are transcendent Forms, they will have to be mobile in order to carry their own Forms to the things occupied. This would contradict the claim that the Forms are at rest. But presumably the solution to this worry is to recognize immanent forms, and as noted earlier, recognizing them entails that there are also transcendent versions of themselves. So those worried by this aspect of the theory being discussed here - or any similar aspect should grant my thesis, that we should understand a Form of Soul as part of the ontology of the Phaedo. My argument is intended to work in part by pointing out how narrow a class of readings is able to avoid acknowledging the Form of Soul.

PLATO, The electronic Journal of the International Plato Society, n 11, 2011.

http://gramata.univ-paris1.fr/Plato/article101.html

(C) All rights of reproduction of any form reserved. 
These two cases are crucial and pivotal, for they appear to mimic the earlier cases of fire, snow and three (just discussed), but in fact they shift to a new pattern that will fit the case of souls occupying bodies. ${ }^{39}$

The first of these new cases looks as if it merely repeats what Socrates has already said about fire and heat, therefore leaving the impression that the Formbringer is the Form of Fire, the physical fire is the thing occupied, and that Heat is the Form brought along. On the other hand, both of these new cases specify the thing occupied as "a body" (sômati, 105b9, c3), just as the case involving the soul will do (105c8), leaving the impression that the new cases also follow the same pattern as the soul-body case. But since the soul-body case is structurally different from the earlier case of fire and heat, this new fire case is a pivot in the argument: it can be read as following either the earlier fire case, or the later soul case, but not both at the same time.

In the earlier cases, those of fire, snow and three, the Form-bringer and the thing occupied were eponymous, and the Form-bringer was itself a transcendent Form. The Form of Fire occupied something, and the thing occupied thereby became a sensible instance of fire. We may read the new fire case in the same way, or we may read it to fit the fever case that follows it. There are two distinct patterns, and Plato has artfully used the fire case here because it can be read following either pattern. The ambiguity creates the impression of continuity where in fact there is a transition.

On the earlier pattern, the Form of Fire occupied a "body," and thereby made that body an instance of fire. The new fire case can be read according to this same pattern, according to which the Form-bringer is eponymous with the thing occupied. But the transitional fire case can also be read to follow the fever and soul examples: an individual fire is the Form-bringer, and it "occupies" some flammable body such as a stick. On this reading, the Form-bringer does not make the thing occupied into an instance of fire, but makes it fiery or causes it to be on fire. Either interpretation seems possible; Plato must have chosen to use fire here at least partly because it can sustain this double reading: this would not have worked for snow or three.

${ }^{39}$ I shall ignore the case of oddness and oneness given at 104c4-6, since mathematical terms present special complications in Plato, and including this case would not change my argument.

PLATO, The electronic Journal of the International Plato Society, n 11, 2011.

http://gramata.univ-paris1.fr/Plato/article101.html

(c) All rights of reproduction of any form reserved. 
But in the fever and soul cases that follow, the Form-bringer cannot be eponymous with the thing occupied. Fever, by occupying a body (it seems clear that sômati must now refer to a human body), does not make it into an instance of fever. ${ }^{40}$ The Form-bringer can therefore only be an individual (instance of) fever, since the body it occupies becomes not a fever, but feverish.$^{41}$ On my reading, a complete description of this case would also say that the individual fever participates in the Form of Fever (that is, that the safe answer remains valid), but this relation is now in the background, and so is no longer mentioned explicitly. Instead, Socrates is focusing on the case in which an individual fever occupies a human body, and the body is made feverish. This differs from the previous pattern (in which the Form-bringer and the thing occupied were eponymous), but presents an exact parallel with the following example, that of the soul, which now follows immediately in the text:

Answer me then... what is it that, present in a body, makes it living? - A soul.

And is that always so? - Of course.

Whatever the soul occupies, it always brings life to it? - It does.

Is there, or is there not, an opposite to life? - There is. What is it? - Death.

So the soul will never admit the opposite of that which it brings along, as we agree from what has been said? $(105 \mathrm{c} 8-\mathrm{d} 11)$

The sophisticated explanation here is that souls occupy (human) bodies, and in doing so make those bodies (not into souls, but) empsuchos, "ensouled" or "alive." The soul plays the role of Form-bringer, occupies a human body, and brings with

${ }^{40}$ The literature treats these cases in many ways. For recent comments, see Ebert (2004, p.388). Philosophers typically try to fit these cases into as few types as possible, and the difficulty comes from the fact that no general scheme fits them all.

${ }^{41} \mathrm{My}$ account here provides some support for the view that there are immanent forms involved in the Phaedo, since I claim that these final examples must be read as including entities such as an individual instance of a fever. The easiest way to understand what this is, seems to be to take it as something like an immanent form. But this may not be forced on us, and I will not pursue the question further here.

PLATO, The electronic Journal of the International Plato Society, n 11, 2011. http://gramata.univ-paris1.fr/Plato/article101.html (c) All rights of reproduction of any form reserved. 
it the Form of Life. ${ }^{42}$ The Form of Life excludes the Form of Death from the body (for as long as the soul occupies it), and by the FEP the soul itself also excludes the Form of Death, for as long as the soul participates in the Form of Life.

What Plato has done, then, is to introduce the pattern of Form-bringers using three putatively simple cases with a common structure: fire, snow and three. But this structure does not match the one he needs for individual souls, so he shifts the structure midstream without calling attention to it. The shift happens over the two additional examples of fire and fever. Rhetorically, the text takes advantage of the sense of clarity conferred by the eponymous relation between Form-bringer and thing occupied in the early examples of fire/snow and three; it then proceeds as if the same simplicity obtained for the later examples. The shift in structure is so artfully hidden that it is hard to believe Plato is unaware of it. ${ }^{43}$ Having changed the structure to the one he needs, Socrates next makes the empirical claim that the presence of a soul makes bodies alive (105c8-10), thus showing that the soul is a Form-bringer. The FEP then allows him to conclude that the soul itself excludes Death. The shift in pattern shows that Form-bringers can be either Forms (as in the examples of fire, snow, and three) or individuals (as in the second case of fire, and that of fever).

These final steps are the important ones for deciding whether the argument for immortality assumes the Form of Soul in the background. The key move in the argument is the claim that individual souls are essentially related to the Form of Life, that is, that there is a necessary and permanent relation of participation between each individual soul and the Form of Life. We need to ask how Socrates intends to justify the necessity and permanence of this relation. My argument assumes that Socrates has some justification in mind for it, and that his introduction of the safe and sophisticated answers, along with the Form-theory they employ, is part of that justification.

${ }^{42}$ The fact that the soul "occupies" the body in a way similar to that in which immanent tallness "occupies" Simmias leads Hackforth and Keyt to think that Plato is treating the soul "like" an immanent form here: Keyt (1963, p.169), Hackforth (1955, p.156). But a soul occupying a body is not a parallel to tallness occupying a body: in one case, the body is made tall simpliciter, while in the other the body is not made into a soul.

43 One might also describe the shift more charitably, as revising or enlarging the definition of Form-bringers. Which description is preferred does not affect my argument.

PLATO, The electronic Journal of the International Plato Society, n 11, 2011.

http://gramata.univ-paris1.fr/Plato/article101.html

(c) All rights of reproduction of any form reserved. 
The proof has two phases, corresponding to two problems Socrates has to solve if he is to prove souls immortal: first, he needs to show that as long as an individual soul exists and is a soul, it is necessarily alive. Call this Phase A; it runs from 102a-105e. But that, of course, is not enough: he must also show that individual souls cannot be destroyed. Socrates needs to show that, unlike lumps of snow, which are necessarily cold so long as they remain lumps of snow, but can also be melted, souls always remain souls. If he can do both, he will have shown the immortality of individual souls. He tries to accomplish the second task in Phase $\mathrm{B}, 105 \mathrm{e}-107 \mathrm{a}$. This part of the argument is obviously inadequate, so the argument does not succeed overall. But this does not prevent us from drawing substantive conclusions about how the argument is supposed to work, based on its goal of showing souls immortal, and on the tools Socrates has given himself for reaching that goal. In what follows, I will argue based on Phase A, showing that the tools and goal of that section require the Form of Soul.

We have established earlier that any reading taking "soul" to refer to an immanent form even once will have to recognize the transcendent Form of Soul. Therefore, we are now concerned only with readings taking "soul" to refer always to individual souls. Suppose, first, that there is no Form of Soul. In this case the argument's key claim will have to be that individual souls partake of the Form of Life necessarily and permanently, without mediation from any other Form. This relation will be a brute fact. The most serious problem with this reading is that Socrates is simply begging the question he is trying to answer. That is, he has given no reason at all for thinking that souls partake of the Form of Life permanently or necessarily. The fact that they bring this Form to bodies cannot establish this stronger relation among souls themselves and Life; just as individual fires can be put out, individual souls might lose their connection to Life, and perish.

Now it might be thought that Socrates does not need to argue for an association between empsuchos and zoos, since in ancient Greek these words were synonymous. But this connection between the two words is not enough to secure the conclusion Socrates wants, namely that whatever is empsuchos will remain permanently zoos. My argument here does not appeal to the fact that Socrates fails to argue for the inference from empsuchos to zoos, but rather to the fact that he fails to argue for the permanence of that connection. Since he does not, he must have some other explanation in mind for his claim that the connection holds

PLATO, The electronic Journal of the International Plato Society, n 11, 2011.

http://gramata.univ-paris1.fr/Plato/article101.html

(c) All rights of reproduction of any form reserved. 
permanently. Surely he does not intend to beg the question. The explanation must be something that can be drawn out of what he actually says, or it will be arbitrary to attribute it to him. In a moment I shall argue that there is such an explanation readily available, based on things Socrates says in the text, and which can explain the permanence he attributes to this relation (even if it cannot provide a valid argument for it). On those grounds, it is the best reading of the final argument. ${ }^{44}$

Readings without a Form of Soul also face two less obvious problems. First, Plato's earlier characterization of Forms and particulars began by assuming the stability and unchangingness of the Forms, and then extending those properties to souls in virtue of whatever degree of resemblance individual souls manage to achieve. Socrates never claims that souls are stable in virtue of any quality of their own. Rather, his view assumes precisely that souls are not stable in their own right. If Socrates is now arguing that souls are stable enough to sustain a permanent and necessary relation to the Form of Life, he is reversing the order of his earlier inference. Because his earlier statements about souls and Forms assumed that souls lack stability in their own right, it is not plausible that he is now claiming that souls are perfectly stable, and thus enjoy a permanent and necessary relation to one of the Forms, in virtue of which they are indestructible.

Second, supposing the last point is wrong - that is, supposing that Socrates does mean to claim (at $80 \mathrm{~b}$ ) that souls are just as stable in their own right as the Forms - there is a problem with the subsequent progress of the discussion. All the characters have agreed at $80 \mathrm{~b}$ that souls are much more like Forms than sensible objects. But the further course of the discussion shows that even this claim leaves room to doubt whether souls are immortal. The assumptions made at $80 \mathrm{~b}$ are thus insufficient to prove souls immortal, and Socrates realizes this. It is unconvincing, then, to suggest that he now recycles this earlier assumption, and tries to use it to finish off the final argument. Nor does anything he has added in the final argument, if combined with this earlier assumption, yield a valid argument that souls have the required relation to the Form of Life.

The alternative is that the Form of Soul should be read as implicit support for Socrates' claim that individual souls have an essential relation to the

${ }^{44}$ I am grateful to an anonymous reader for raising this criticism.

PLATO, The electronic Journal of the International Plato Society, n 11, 2011.

http://gramata.univ-paris1.fr/Plato/article101.html

(c) All rights of reproduction of any form reserved. 
Form of Life. Now, since Socrates' overall argument does not succeed, this reading cannot claim to produce a valid argument any more than the first reading I have just rejected. But it can describe a line of thought that is plausible and coherent, and thus makes better sense of the moves Socrates makes in the course of the argument.

There are three positive reasons for thinking that the Form of Soul must be involved in the final argument. First, using the Form of Soul, there is a straightforward explanation of how Socrates may want to justify his claim that souls are essentially related to the Form of Life. The "safe" answers, including what is said about the Forms of Three, Snow, and Fire, are introduced to show that every individual (i.e. non-Form) item and property has one permanent and necessary relation, namely that with its eponymous Form. It follows from this claim that individual souls have the necessary property of being souls. Put in terms of the Form-theory, this means that individual souls necessarily participate in the Form of Soul. This necessary and permanent property is the best place to look for the necessity and permanence in the relation between souls and the Form of Life. The eponymous relation to a thing's own Form must persist so long as the thing or property remains what it is. So long as a hula-hoop remains a hula-hoop, it is logically certain that it participates in the Form of Hula-Hoop; so long as souls are souls, they must participate in the Form of Soul.

It is not hard to see why Socrates would prefer to explain the participation of individual souls in the Form of Life via their participation in the Form of Soul. The theory of the Phaedo emphasizes at every turn that stability and permanence are found only in the Forms, while non-Form items are notoriously unstable. It would therefore be surprising to suggest that there can be necessary and permanent relations unless the relata are themselves permanent; the sole exception to this rule seems to be the eponymous relation that underwrites Socrates' "safe" answers. The eponymous relations have conditional necessity, but no permanence. Their necessity is of the form, "so long as this $\mathrm{x}$ is F, it necessarily participates in the Form F." But no individual item or property has permanence tout court, so if there are any relations that are absolutely necessary and permanent, we should expect to find them holding only between transcendent Forms. For those things that have necessary properties in addition to their eponymous property of being what they are, these further properties should therefore be explained by relations among Forms, not by relations directly

PLATO, The electronic Journal of the International Plato Society, n 11, 2011.

http://gramata.univ-paris1.fr/Plato/article101.html

(c) All rights of reproduction of any form reserved. 
between individuals and Forms. Thus, sensible snow necessarily participates in the Form of Snow, and this Form necessarily brings the Form of Cold with it. In virtue of this relation, sensible snow is also obliged to participate in the Form of Cold, and thus prevented from participating in the Form of Heat. Souls should work the same way: individual souls necessarily participate in the (eponymous) Form of Soul. Since all Forms are perfectly stable, a relation between the Forms of Soul and Life will also be perfectly stable. Once anything is an individual soul, then, it will go on stably participating in the Forms of both Soul and Life, and thus remain alive permanently and necessarily. This version of the argument is, of course, also flawed. It fails to give any reason for thinking that souls must always participate in the Form of Soul, even if we grant Socrates the assumption that the Form of Soul implies a permanent connection to the Form of Life. Nevertheless, this version of the argument is interesting and inventive, and one can grant that it has some plausibility if not scrutinized too closely. This is an argument worthy of ascription to Plato, whereas the alternative without the Form of Soul reduces to question-begging shrouded in what turn out to be irrelevant complications.

A second argument for recognizing the Form of Soul is that if there is no such Form, the safe answers are no longer safe when we reach the part of the proof concerned with souls. For the safe answers depend on there being a Form available to explain any property one might ask about, including the property of being a particular sort of thing. So if there is no Form of Soul, we should expect some hint that these answers are no longer valid unless accompanied by a separate argument that the Form being invoked exists. But this is not what we find in the text. Instead, Socrates continues to use the safe answers all the way to $106 \mathrm{~d}$, and never feels any need to argue that the Forms he mentions actually exist. If the safe answers work for some entities but not for others, Socrates should give up calling them asphalê - the point of this epithet is just that they always work. So the presumption must be that the safe answer works for souls as well, the more so because souls are the raison d'etre of the entire argument. When Socrates introduces his last two examples (fire and fever) just before getting to souls, he says, "beyond that safe answer, which I spoke of first, I see another safe answer" (par' hên to prôton elegon apokrisin, tên asphalê ekeinên, ek tôn nun legomenôn allên horôn asphaleian, 105b7-8). He is not rejecting the first kind of safe answer, only proposing an additional safe answer. We see this when he rehearses the (first kind of) safe answer at each stage in his subsequent speech, explaining the new, more "sophisticated" answers he is now seeking:

PLATO, The electronic Journal of the International Plato Society, n 11, 2011.

http://gramata.univ-paris1.fr/Plato/article101.html

(C) All rights of reproduction of any form reserved. 
"If you should ask me what, coming into a body, makes it hot, my reply would not be that safe and ignorant one, that it is heat...and if you ask me what, on coming into a body, makes it sick, I will not say sickness...[and] if asked the presence of what in a number makes it odd, I will not say oddness..." (105b8-5)

For Socrates, then, the initial safe answers remain perfectly acceptable. Since they are woven thickly into the final stages of the argument, there is at least a presumption that they continue to be safe. And if they remain safe, there must be a Form of Soul.

A third argument for the Form of Soul notes that the first move in the final argument is to re-introduce the Forms. "I assume the existence of a Beautiful, itself by itself, of a Good and a Great and all the rest. If you grant me these and agree that they exist, I hope to show you the cause as a result, and to find the soul to be immortal" (100b5-9). Socrates thus indicates that some Forms are necessary for his argument.

Now if souls participate in the Form of Life without the mediation of a Form of Soul, it will not have been necessary to invoke Forms in general. The argument's key claim will just be that souls are essentially alive. Putting that claim in a form that mentions the Form of Life cannot show that souls are necessarily or permanently alive. All we know about the Form of Life is that it is the essence of Life, or that it is what it is to be alive, and this much implies no connection with souls. There is thus no way of reaching Socrates' conclusion using only the Form of Life.

It is worth emphasizing that Socrates says nothing to justify the claim that individual souls must always participate in the Form of Life. Individual souls, according to his own account of them, are sometimes very unstable. If they are unstable with respect to other properties, there is no reason for assuming - and Socrates does not try to argue - that they will be stable with respect to the property of life. Nor is there any logical connection between souls and life or souls and the Form of Life. The problem arises precisely because there is no such connection: it is all too easy to imagine that souls can die or be destroyed.

PLATO, The electronic Journal of the International Plato Society, n 11, 2011.

http://gramata.univ-paris1.fr/Plato/article101.html

(c) All rights of reproduction of any form reserved. 
It must therefore be the case that Socrates needs at least one other Form for his proof. He mentions several as he leads up to his conclusion: the Forms of Three, Snow, Fire, etc. But these have no application (apart from drawing analogies) to the case of souls, so they cannot aid his proof. So there is at least one Form that Socrates needs for his proof, but it is neither the Form of Life, nor Three, nor Oddness, Snow, Fire, etc. By elimination, it looks as if the Form Socrates needs can only be the Form of Soul.

We should therefore read this argument, as well as Socrates' earlier statements about Forms, as assuming a Form of Soul along with a vast range of other Forms.

Having now given the reasons for recognizing the Form of Soul behind the explicit metaphysical scenery in the text, it is now time to respond to the argument against that Form's existence that I mentioned above, given by Monique Dixsaut. She writes,

“[S'il y avait une Forme de l'Ame,] Un autre type d'argumentation serait requis : il faudrait montrer qu'une âme ne peut jamais cesser de participer à l'idée d'Ame. On est libre de penser que Platon aurait dû poser cette question : force est de constater que, ni dans le Phédon ni ailleurs, il ne la pose. ${ }^{45}$

While Dixsaut notes correctly that there is no argument in so many words that souls can never stop participating in the Form of Soul, she overlooks the presence in the text of a logically equivalent argument at 105e11-107a1. This is what I earlier called Phase B; here Socrates tries unsuccessfully to argue that souls, being "deathless," are therefore also indestructible. Regardless of the fact that this part of the argument is a failure, this is logically equivalent to the argument Dixsaut finds lacking. For it has been established in Phase A that so long as a soul is a soul, it necessarily participates in the Form of Soul, and also that anything participating in the Form of Soul also participates in the Form of Life. So souls participate in the Form of Life so long as they are souls. If they should stop participating in the Form of Soul, they would no longer necessarily participate in the Form of Life. And if they stopped participating in the Form of Life, they

${ }^{45}$ Dixsaut (1991, p.397, n.321)

PLATO, The electronic Journal of the International Plato Society, n 11, 2011.

http://gramata.univ-paris1.fr/Plato/article101.html

(C) All rights of reproduction of any form reserved. 
might then participate in the Form of Destruction. It follows that if souls never participate in the Form of Destruction, they never stop participating in the Form of Soul. The argument in Phase B is therefore logically equivalent to the one Dixsaut mentions as missing from the text. Nor is the logic here at all involved; the reasoning is simple enough to be plausibly ascribed to Plato and/or Socrates.

Finally, it might be thought that there is something wrong with any conclusion that admits a Form of Soul, for there is something discomfiting about such a Form. This objection can be answered quickly. For the Phaedo's final argument explicitly involves Forms of Life and Death, and these will give rise to difficulties similar to those prompting this kind of objection to a Form of Soul. A Form of Death may be even worse than that of Life, if it is a Form of the destruction or separation of something. But the structure of the argument requires the Form of Death (105d9), since the argument is built around pairs of opposite Forms. Since Plato permitted himself Forms of Life and Death, it is hard to object to the Form of Soul for this reason.

I have argued, first, that the theory held by Socrates in the Phaedo includes very many Forms, a set not limited by any logical consideration so far identified in the text. Given this range of Forms, a Form of Soul must be one of the Forms Socrates would be prepared to recognize. Second, the final argument for immortality, although unsuccessful on any reading, turns out considerably weaker on readings denying a Form of Soul - so much weaker that these readings would need to offer some strong justification for taking the argument this way.

PLATO, The electronic Journal of the International Plato Society, n 11, 2011.

http://gramata.univ-paris1.fr/Plato/article101.html

(c) All rights of reproduction of any form reserved. 


\section{REFERENCES}

AnNAS, Julia. 1981. An introduction to Plato's Republic. Oxford University Press.

Archer-Hind, R. D. 1894. The Phaedo of Plato. New York: Arno Press.

BESTOR, Thomas Wheaton. 1988. "Plato's Phaedo and Plato's Essentialism." Australasian Journal of Philosophy 66:26-51.

BosTock, David. 1986. Plato's Phaedo. Oxford: Clarendon Press.

Burnet, John. 1911. Plato’s Phaedo. Oxford: Clarendon Press.

Cooper, John M. 2002. Plato: Five Dialogues (Euthyphro, Apology, Crito, Meno, Phaedo). Indianapolis: Hackett.

CRIVELLI, Paolo. 2008. “Plato's Philosophy of Language.” In Gail Fine (ed.), The Oxford Handbook of Plato, 217-242. Oxford University Press.

DANCY, R.M. 2004. Plato's Introduction of Forms. Cambridge University Press.

Devereux, Daniel. 2003. "Plato: Metaphysics." In Christopher Shields (ed.), The Blackwell Guide to Ancient Philosophy. Oxford: Blackwell.

DiXSAUT, Monique. 1991. Platon: Phédon. Paris: Flammarion.

DORTER, Kenneth. 1982. Plato's Phaedo: An Interpretation. University of Toronto Press.

EBERT, Theodor. 2004. Platon: Phaidon. Vandenhoeck \& Ruprecht.

FincK, Florian. 2007. Platons Begründung der Seele im absoluten Denken. De Gruyter.

FINE, Gail. 1987. “Forms as Causes: Plato and Aristotle.” In Gail Fine (ed.), Plato on Knowledge and Forms, 350-396. Oxford University Press.

PLATO, The electronic Journal of the International Plato Society, n 11, 2011.

http://gramata.univ-paris1.fr/Plato/article101.html

(c) All rights of reproduction of any form reserved. 
—. 1993. On Ideas. Oxford: Clarendon Press.

Gallop, David. 1975. Phaedo. Oxford: Clarendon Press.

GILl, Christopher and McCabe, Mary Margaret. 1996. Form and Argument in Late Plato. Oxford: Clarendon Press.

Griswold, Charles. 1981. "The Ideas and the Criticism of Poetry in Plato's Republic, Book 10." Journal of the History of Philosophy 19.

-. 1986. Self-knowledge in Plato's Phaedrus. Yale University Press.

Gueroult, M. 1926. "La Méditation de l'Âme sur l'Âme dans le "Phédon”." Revue de Métaphysique et de Morale 33:469-491.

Hackforth, R. 1955. Plato: Phaedo. Cambridge University Press.

HARTE, Verity. 2008. "Plato's Metaphysics." In Gail Fine (ed.), The Oxford Handbook of Plato. Oxford University Press.

KEYT, David. 1963. “The Fallacies in 'Phaedo' 102a-107b.” Phronesis 8:167172.

LEVIN, Susan B. 2001. The ancient quarrel between philosophy and poetry revisited Plato and the Greek literary tradition. Oxford University Press.

Loriaux, Robert. 1975. Le Phédon de Platon, Volume 2 (84b-118a). Namur: Presses universitaires de Namur.

MALCOLM, John. 1991. Plato on the self-predication of forms : early and middle dialogues. Oxford University Press.

MoraVCSIK, J. M. E. 2000. Plato and Platonism : Plato's conception of appearance and reality in ontology, epistemology, and ethics, and its modern echoes. Oxford: Blackwell.

PLATO, The electronic Journal of the International Plato Society, n 11, 2011.

http://gramata.univ-paris1.fr/Plato/article101.html

(C) All rights of reproduction of any form reserved. 
Nehamas, Alexander. 1973. "Predication and Forms of Opposites in the Phaedo." Review of Metaphysics 26:461-491.

-. 1975. "Plato on the Imperfection of the Sensible World." American Philosophical Quarterly 12:105-117.

PATTERSON, Richard. 1985. Image and reality in Plato's metaphysics. Indianapolis: Hackett.

RiCKLESS, Samuel C. 2007. Plato's Forms in Transition. Cambridge University Press.

Silverman, Allan. 2002. The Dialectic of Essence. Princeton University Press.

White, F. C. 1978. "The Phaedo and Republic V on Essences." The Journal of Hellenic Studies 98:142-156.

White, Nicholas P. 1979. A companion to Plato's Republic. Oxford: Blackwell.

PLATO, The electronic Journal of the International Plato Society, n 11, 2011.

http://gramata.univ-paris1.fr/Plato/article101.html

(c) All rights of reproduction of any form reserved. 